\title{
Gene-flow within a butterfly metapopulation: the marsh fritillary Euphydryas aurinia in western Bohemia (Czech Republic)
}

\author{
Marius Junker ${ }^{1} \cdot$ Martin Konvicka $^{2,3} \cdot$ Kamil Zimmermann $^{3,4} \cdot$ Thomas Schmitt $^{5,6,7}$ (D)
}

Received: 4 December 2020 / Accepted: 24 May 2021 / Published online: 6 June 2021

(c) The Author(s) 2021

\begin{abstract}
In human-altered landscapes, species with specific habitat requirements tend to persist as metapopulations, forming colonies restricted to patches of suitable habitats, displaying mutually independent within-patch dynamics and interconnected by inter-colony movements of individuals. Despite intuitive appeal and both empirical and analytical evidence, metapopulations of only relatively few butterfly systems had been both monitored for multiple years to quantify metapopulation dynamics, and assayed from the point of view of population genetics. We used allozyme analysis to study the genetic make-up of a metapopulation of a declining and EU-protected butterfly, Euphydryas aurinia, inhabiting humid grasslands in western Czech Republic, and reanalysed previously published demography and dispersal data to interpret the patterns. For 497 colony $\mathrm{x}$ year visits to the 97 colonies known at that time, we found annual extinction and colonisation probabilities roughly equal to $4 \%$. The genetic diversity within colonies was intermediate or high for all assessed parameters of population genetic diversity and hence higher than expected for such a habitat specialist species. All the standard genetic diversity measures were positively correlated to adult counts and colony areas, but the correlations were weak and rarely significant, probably due to the rapid within-colony population dynamics. Only very weak correlations applied to larval nests numbers. We conclude that the entirety of colonies forms a well-connected system for their majority. Especially in its core parts, we assume a metapopulation structure with a dynamic equilibrium between local extinction and recolonization. It is vital to conserve in particular these structures of large and interconnected colonies.

Implications for insect conservation: Conservation measures should focus on considering more in depth the habitat requirements of E. aurinia for management plans and on stabilisation strategies for colonies, especially of peripheral ones, e.g. by habitat restoration.
\end{abstract}

Keywords Allozymes $\cdot$ Butterfly conservation $\cdot$ Metapopulation genetics $\cdot$ Lepidoptera $\cdot$ Melitaeini $\cdot$ Nymphalidae . Population dynamics $\cdot$ Temperate humid grasslands

Thomas Schmitt

thomas.schmitt@senckenberg.de

1 Biogeography, Faculty of Regional and Environmental Studies, Trier University, D-54286 Trier, Germany

2 Faculty of Sciences, University South Bohemia, Branisovska 312, 37005 Ceske Budejovice, Czech Republic

3 Institute of Entomology CAS, Branisovska 312, 37005 Ceske Budejovice, Czech Republic

4 Department of Environment, Agriculture and Forestry, Landscape Ecology and NATURA 2000, U Zimního stadionu 1952/2, 37076 České Budějovice, Czech Republic
5 Senckenberg German Entomological Institute, Eberswalder Straße 90, D-15374 Müncheberg, Germany

6 Entomology, Zoology, Institute of Biology, Faculty of Natural Sciences I, Martin Luther University Halle-Wittenberg, D-06099 Halle (Saale), Germany

7 Entomology and Biogeography, Institute of Biochemistry and Biology, Faculty of Science, University of Potsdam, D-14476 Potsdam, Germany 


\section{Introduction}

Metapopulations are sets of populations inhabiting spatially separated habitat patches and displaying mutually independent within-patch dynamics, including local extinctions, which are counterbalanced by recolonisation from occupied patches (Hanski 1999; Colombo and Anteneodo 2015). As many species persist in habitat remnants within increasingly human-dominated landscapes (e.g. Slancarova et al. 2014; Nabielec and Nowicki 2015; Shuey et al. 2016), understanding the colonisation/extinction processes responsible for metapopulation persistence has become paramount for efficient conservation at the landscape level (Hill et al. 1996; Baguette et al. 2000; Baguette 2003; Kadlec et al. 2010; Hanski et al. 2017).

Originally, the metapopulation dynamics was interpreted with emphasis on demographic and environmental processes with little consideration of intraspecific genetic variation and natural selection (Hanski 1999), apart from inbreeding depression reducing population growth in small populations (e.g. Saccheri et al. 1998; Madsen et al. 1999). This has gradually changed, and genetic processes in metapopulations are increasingly targeted (Habel and Schmitt 2012, 2018; Hanski et al. 2017). For instance, isolation can decrease gene flow, and hence disrupt the processes maintaining within-population diversity (e.g. Madsen et al. 2000; Újvári et al. 2002; Sigaard et al. (2008); Habel et al. 2012, 2019), whereas dispersal among habitat patches maintains a high within-population diversity (Schmitt et al. 2003, 2005a, b; Habel et al. 2010; Kramp et al. 2016). Comparative studies of Louy et al. (2007, 2014), Habel and Schmitt (2009) and Habel et al. (2010) emphasised the importance of dispersal strategies and abilities. To maintain genetic diversity, sedentary species tend to build up high density populations, whereas mobile species can persist under lower local abundances (cf. Habel and Schmitt 2009; Konvicka et al. 2012; for an overview see Habel and Schmitt 2018). However, current population genetic patterns also may reflect past spatial structures in many cases, rather than recent landscape patterns (e.g. Schmitt et al. 2000; Orsini et al. 2008).

So far, a comprehensive understanding of the interaction between demographic patterns, population genetic structures and species viability in landscapes remains limited to a few study systems, for which the necessary information (distribution of colonies and their occupancy, their viability, within-colony population structure) is available. One such system is the Czech metapopulation of the Marsh fritillary, Euphydryas aurinia (Rottenburg, 1775) (Lepidoptera: Nymphalidae), an EU protected butterfly inhabiting semi-natural nutrient-poor grasslands of Europe and temperate Asia (Tshikolovets 2011). This system, consisting of a minimum of 100 colonies distributed over $1,500 \mathrm{~km}^{2}$ at the western fringe of the country, has been monitored for over a decade, and studied with focus on larval habitat requirements, adult population structure and dispersal (Konvicka et al. 2003; Fric et al. 2010). While most of the local colonies are rather small, harbouring dozens of adult individuals, several large colonies host thousands of butterflies, and the whole Czech population produces about 20,000 adults per year (Zimmermann et al. 2011a). Despite sometimes long distances separating local populations, dispersal between colonies exists, and colonies as distant as $10 \mathrm{~km}$ one from the other still have a chance to exchange dispersing females (Fig. 1; Zimmermann et al. 2011a).

In this study, we combine allozyme polymorphisms, as measure for genetic diversity and differentiation, with demography and dispersal information, obtained by earlier field surveys, to obtain deeper insights into the Czech

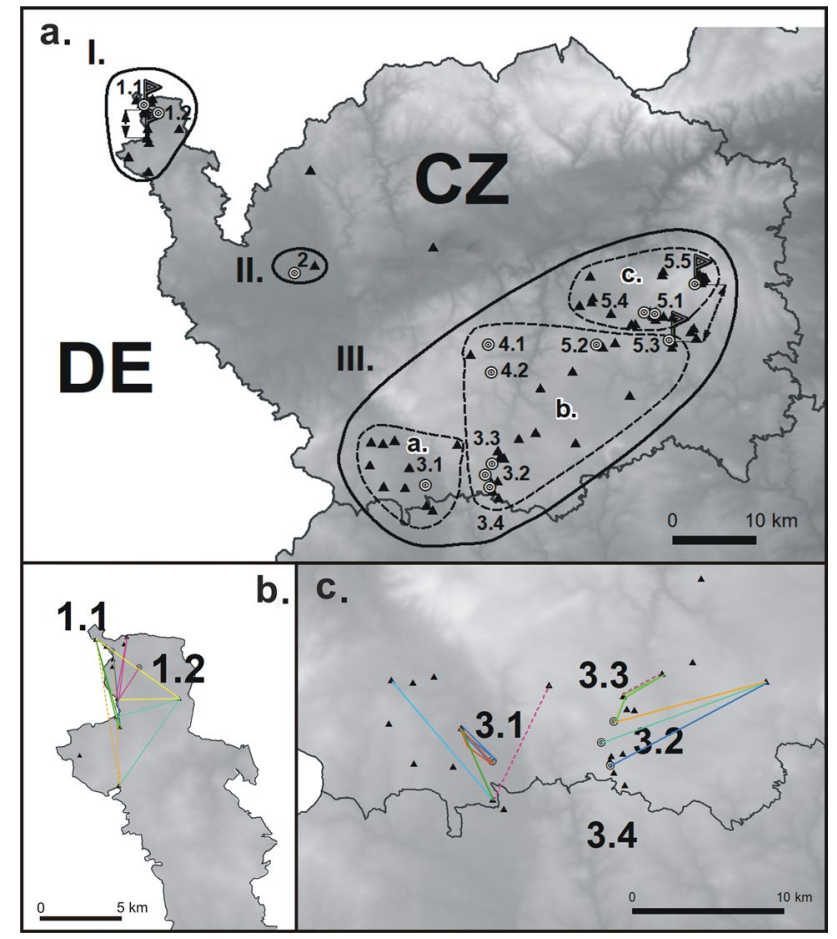

Fig. 1 Euphydryas aurinia colonies in western Czech Republic (Karlovy Vary region) and examples of inter-colony movements. a Positions of all local colonies known before 2010 (black triangles), including the 14 colonies sampled for allozyme analyses (circles), and the three clusters, I., II. and III., delimited according to geography and genetic distances (Nei 1972). Continuous lines: geographic colony groups (distance between groups $>15 \mathrm{~km}$ ); broken lines: genetic subgroups within the geographic group III. Dashed dart: the longest recorded individual movement. b, c Two detailed sections of the E. aurinia distribution area, with the longest male (solid lines) and female movement trajectory (dashed lines) recorded within these sections during the mark-recapture study of Zimmermann et al. (2011b) 
Republic E. aurinia metapopulation dynamics. We first summarise the evidence for a metapopulation dynamics of the system, based on a decade of monitoring. Second, we describe the spatial genetic structure of the metapopulation. Finally, we investigate if there is a detectable link between the local genetic make-up of individual colonies and demographic markers of the colonies' viability (such as population size, variation in population size, connectivity measures based on spatial distribution of colonies).

\section{Material and methods}

\section{The species}

Euphydryas aurinia (Rottenburg, 1775) is a polymorphic species (Junker et al. 2015; Korb et al. 2016), inhabiting a wide range in the Palaearctic temperate zones (Tshikolovets 2011) and displaying multiple regional habitat and host plant specialisations (Singer et al. 2002; Junker and Schmitt 2010; Junker et al. 2010; Meister et al. 2015). However, the bulk of the populations in Central and Western Europe, less the Alps, inhabits nutrient-poor semi-natural grasslands, often developing on Succisa pratensis, a late summer to autumn flowering forb. Due to the loss of such grasslands, the species is threatened in most of Western and Central Europe and has been listed on annex II of the EU Habitats Directive. Females of this univoltine butterfly lay egg batches at the underside of host plant leaves, preferring plants growing at short-sward patches within the grasslands (Konvicka et al. 2003). Larvae develop in communal nests until overwintering and continue feeding solitarily in spring. Adult flight lasts three to four weeks from May to July, depending on climate, weather and altitude (Junker et al. 2010; Zimmermann et al. 2010).

\section{Study system}

The Czech E. aurinia distribution is restricted to the Karlovy Vary region, the westernmost part of the country, where a sizeable proportion of semi-natural grasslands has remained unaffected by farming intensification owing to the existence of a military area, two freshwater accumulation reservoirs, numerous mineral water sources, and a depopulated borderland separating former Eastern and Western blocks (Zimmermann et al. 2010). Within this region, three distinct subareas are occupied by the butterfly (Fig. 1a).

From the West, the first sub-area adjoining Czech/Germany borders is situated in Smrčiny/Fichtel Mts. (highest point: Schneeberg, $1051 \mathrm{~m}$ a.s.l.), gently rolling system of Variscan origin, built from crystalline rocks and mainly covered by Picea abies plantations $(\approx 60 \%$ of the area, the rest are mainly hay meadows and pastures). The colonies are found on nutrient-poor humid grasslands adjoining streams separating the two countries; their average elevation is $577 \mathrm{~m}$ a.s.l. ( \pm 27.4 SD, range 540-640). To the Southeast, a few colonies exist on boggy grasslands of the flat Chebská Pan (Soos nature reserve, $440 \mathrm{~m}$ a.s.1.), covered by marshland prehistorically but mostly intensively cultivated at present. Still further to the Southeast, following the SW-NE flow of the Ohře river, the bulk of the Czech distribution is situated, mostly on the elevated plateaux of the Tertiary volcanic Doupovské Mts. (maximum elevation: Hradiště, 934 m a.s.1.) and Slavkovský les Mts. (Lesný, 983 m a.s.1.), and some on the eastern slopes of crystalline Variscan Český les Mts. In this region, the colonies are found at mid-elevations of the mountains (average elevation: $683 \mathrm{~m}$ a.s.1. $\pm 72.1 \mathrm{SD}$, range 520-810), at patches of nutrient-poor humid grasslands $(\approx 5 \%$ of the entire area), preserved mostly at boggy waterlogged sites (springs, brook banks, banks of locally common fish ponds, etc.). Other land covers include improved grasslands $(\approx 40 \%$ ) used mainly as beef cattle pastures, or for intensive hay production, and woodlands ( $\approx 40 \%)$, with prevailing $P$. abies plantations (Český les, Slavskovský les) and sparse Betula pendula-Sorbus aucuparia-Pinus sylvestris groves. The rest is settlements, arable land and water bodies.

Since 2001, when only seventeen $E$. aurinia sites were known to conservationists within this region, intensive searches for colonies, plus annual counts of communal larval nests in the first decade of September, a standard method for E. aurinia surveys (Hula et al. 2004; Schtickzelle et al. 2005), had been carried out. By autumn 2010, a total of 97 colony patches were known (Fig. 1a) and larval counts were available for 497 colony-year combinations (Table 1). Seventeen of these colonies were monitored for ten years, whereas eight for only one year (average number of monitoring years
Table 1 Overview of $E$. aurinia colony monitoring data, situation in autumn 2009, with detected extinctions and recolonisations

\begin{tabular}{llllll}
\hline & Colony *years & $\begin{array}{l}\text { Detected } \\
\text { extinc- } \\
\text { tions }\end{array}$ & $\begin{array}{l}\text { Detected } \\
\text { recolonisa- } \\
\text { tions }\end{array}$ & $\begin{array}{l}\text { Repeated } \\
\text { extinctions }\end{array}$ & $\begin{array}{l}\text { Repeated } \\
\text { recolonisa- } \\
\text { tion }\end{array}$ \\
\hline All known colonies $(\mathrm{n}=97)$ & 497 & 40 & 15 & 4 & 1 \\
Monitored since 2001 $(\mathrm{n}=17)$ & 96 & 17 & 6 & 3 & 1 \\
Allozyme sampled colonies $(\mathrm{n}=14)$ & 98 & 2 & 2 & 1 & 1 \\
\hline
\end{tabular}

From initial 17 colonies known in 2001, when the annual monitoring of larval nests started, further 80 colonies were discovered until 2010. Hence, not all colonies were monitored for all years 
per colony: $4.5 \pm 0.26 \mathrm{SD}$, median: 4.0$)$. The total summed area of all known colonies was 389 ha (mean per colony: $4.1 \mathrm{ha} \pm 0.63 \mathrm{SD}$; range $0.03-36$ ha, median: $1.7 \mathrm{ha}$ ), the mean distance to the nearest colony was $128 \mathrm{~m} \pm 249 \mathrm{SD}$ (range: 10-2,320 m, median: $72 \mathrm{~m}$ ) and the average patchto-patch distance, including the most distant colonies in the system, was 2,980 m $\pm 301 \mathrm{SD}$, median: $260 \mathrm{~m}$.

To describe the local demography patterns, a single system of patches was followed for eight years (2002-2010) using mark-recapture (MR) of adults, and practically all colonies occupied in $2007(n=83)$ were studied using MR in that year (Zimmermann et al. 2011a). Within the single system, adult female numbers fluctuated (with $\mathrm{CV}=0.501$ ) more than male numbers $(\mathrm{CV}=0.428)$ (sexes combined: $\mathrm{CV}=0.397$ ). Adult density per hectare of habitat ranged from 90 to 120 individuals, exhibiting a density-dependent relationship to colony size from previous years. The beginning and peak of the flight season varied by 18 days among sites and years, depending on weather and altitude. The estimated total Czech population size was 25,000 individuals (16,000 males, 9,000 females) in 2007.

During the all colonies MR campaign, we detected several long-distance movements: 51 individuals crossed $5 \mathrm{~km}$ (41 males, 10 females), and 14 crossed $10 \mathrm{~km}$ (13 males, 1 female); examples in Fig. 1b, c. Fitting the inverse power dispersal kernels revealed a considerable variation among colonies and years in dispersal propensities, but predicted that all Czech colonies were within $0.1 \%$ dispersal probability of both sexes (corresponding to 17 males and 9 females likely to move between the most distant colonies in 2007) (Zimmermann et al. 2011b). If the more stringent 1\% probability of movements is considered, the colonies would form three distinct clusters: I.-Western, at the Czech-German border; II.-Central, the Soos reserve with its surroundings; and III.-Eastern, a unit that includes the Doupovské Mts., Slavkovský les Mts., and the northern part of the Český les Mts. (cf. Zimmermann et al. 2011b) (Fig. 1a).

\section{Butterfly sampling and electrophoresis}

We sampled 14 colonies (Table 2) out of the 83 occupied in 2007 for population genetic analysis. They included a balanced representation of large and small, isolated and connected colonies from the entire Czech distribution. We sampled a total of 336 males, all of them in the late flight season to minimise interfering with the concurrent MR campaign and to minimise the impact on colonies. As by the time the study was performed non-lethal methods in population genetic analyses were still not standard, we used a technique in need of using entire individuals; however, by the highly sensitive way of only sampling old males, we can guarantee that none of the studied populations was negatively influenced by our study in the follow-up generations. Sample sizes per colony ranged from ten to 36 individuals (mean:
Table 2 The 14 populations of E. aurinia in western Czech Republic sampled for this study, with their geographic positions, sample sizes $(N)$, percentage of the sampled individuals from estimated total number of the respective colony $\left(\% N_{\text {est }}\right)$ and obtained parameters of genetic diversity: Expected heterozygosity $\left(H_{\mathrm{e}}\right)$, observed heterozy- gosity $\left(H_{\mathrm{o}}\right)$, total percentage of polymorphic loci $\left(P_{\text {tot }}\right)$, percentage of polymorphic loci with the most common allele not exceeding $95 \%$ $\left(P_{95}\right)$, mean number of alleles per locus $(A)$, allelic richness regarding colonies with individual numbers being at least $23\left(A_{\mathrm{R} 23}\right)$, and allelic richness regarding all colonies $\left(A_{\mathrm{R}}\right)$

\begin{tabular}{|c|c|c|c|c|c|c|c|c|c|c|c|c|}
\hline Code & Local name & $N$ & $\% N_{\text {est }}$ & Latitude & Longitude & $H_{\mathrm{e}}(\%)$ & $H_{\mathrm{o}}(\%)$ & $P_{\text {tot }}(\%)$ & $P_{95}(\%)$ & $A$ & $A_{\mathrm{R} 23}$ & $A_{\mathrm{R}}$ \\
\hline 1.1 & Lužni potok & 23 & 19.33 & $50^{\circ} 17^{\prime} \mathrm{N}$ & $12^{\circ} 08^{\prime} \mathrm{E}$ & 15.7 & 13.6 & 58.8 & 41.2 & 2.00 & 2.00 & 1.76 \\
\hline 1.2 & Trojmezi & 25 & 2.91 & $50^{\circ} 18^{\prime} \mathrm{N}$ & $12^{\circ} 06^{\prime} \mathrm{E}$ & 17.2 & 16.5 & 70.6 & 52.9 & 2.18 & 2.16 & 1.90 \\
\hline 2 & Soos & 24 & 0.70 & $50^{\circ} 08^{\prime} \mathrm{N}$ & $12^{\circ} 25^{\prime} \mathrm{E}$ & 13.6 & 14.7 & 70.6 & 52.9 & 1.94 & 1.93 & 1.71 \\
\hline 3.1 & Ušovice & 16 & 6.48 & $49^{\circ} 55^{\prime} \mathrm{N}$ & $12^{\circ} 49^{\prime} \mathrm{E}$ & 16.8 & 17.3 & $(52.9)$ & 41.2 & $(1.77)$ & - & 1.67 \\
\hline 3.2 & Horní Kramolín & 25 & 0.54 & $49^{\circ} 58^{\prime} \mathrm{N}$ & $12^{\circ} 48^{\prime} \mathrm{E}$ & 16.5 & 16.7 & 64.7 & 52.9 & 2.18 & 2.14 & 1.85 \\
\hline 3.3 & Ovesné Kladruby & 25 & 1.87 & $49^{\circ} 57^{\prime} \mathrm{N}$ & $12^{\circ} 47^{\prime} \mathrm{E}$ & 12.0 & 12.8 & 58.8 & 47.1 & 2.00 & 1.99 & 1.75 \\
\hline 3.4 & Bezvěrov & 30 & 4.17 & $49^{\circ} 56^{\prime} \mathrm{N}$ & $12^{\circ} 48^{\prime} \mathrm{E}$ & 12.8 & 12.4 & 64.7 & 52.9 & 2.12 & 2.02 & 1.70 \\
\hline 4.1 & Krásno & 30 & 2.90 & $50^{\circ} 05^{\prime} \mathrm{N}$ & $12^{\circ} 44^{\prime} \mathrm{E}$ & 12.1 & 11.6 & 64.7 & 52.9 & 2.12 & 2.04 & 1.73 \\
\hline 4.2 & Dominova skalka & 23 & 1.28 & $50^{\circ} 04^{\prime} \mathrm{N}$ & $12^{\circ} 46^{\prime} \mathrm{E}$ & 15.6 & 16.1 & 64.7 & 52.9 & 1.82 & 1.82 & 1.68 \\
\hline 5.1 & Horni Tašovice & 10 & 9.71 & $50^{\circ} 10^{\prime} \mathrm{N}$ & $13^{\circ} 00^{\prime} \mathrm{E}$ & 12.3 & 12.4 & $(52.9)$ & 52.9 & $(1.59)$ & - & 1.59 \\
\hline 5.2 & Kounice & 18 & 0.98 & $50^{\circ} 07^{\prime} \mathrm{N}$ & $12^{\circ} 56^{\prime} \mathrm{E}$ & 9.3 & 9.8 & $(47.1)$ & 35.3 & $(1.65)$ & - & 1.51 \\
\hline 5.3 & Údrč & 25 & 10.68 & $50^{\circ} 08^{\prime} \mathrm{N}$ & $13^{\circ} 03^{\prime} \mathrm{E}$ & 12.2 & 12.0 & 58.8 & 41.2 & 1.82 & 1.81 & 1.63 \\
\hline 5.4 & Bochov & 26 & 1.16 & $50^{\circ} 10^{\prime} \mathrm{N}$ & $13^{\circ} 01^{\prime} \mathrm{E}$ & 12.3 & 12.9 & 52.9 & 47.1 & 1.71 & 1.69 & 1.56 \\
\hline 5.5 & Znělec & 36 & 0.54 & $50^{\circ} 12^{\prime} \mathrm{N}$ & $13^{\circ} 05^{\prime} \mathrm{E}$ & 15.6 & 14.9 & 64.7 & 58.8 & 2.12 & 2.00 & 1.78 \\
\hline mean & & 24.0 & 4.50 & & & 13.9 & 13.8 & 63.1 & 48.7 & 2.00 & 1.96 & 1.70 \\
\hline$\pm \mathrm{SD}$ & & 6.34 & 5.41 & & & 2.4 & 2.2 & 5.3 & 6.8 & 0.16 & 0.14 & 0.11 \\
\hline
\end{tabular}

Values excluded for the calculations of means in the cases of $P_{\text {tot }}$ and $A$ (due to insufficient number of analysed individuals) are given in parentheses 
$24.0 \pm 6.3 \mathrm{SD})$, and included, on average, $4.5 \%( \pm 5.4 \mathrm{SD})$ of the respective colonies`estimated adult abundance. Only three samples contained less than 20 individuals (Table 2; Fig. 1).

After netting in the field, the butterflies were immediately frozen in liquid nitrogen and stored until analysis. The whole abdomen of each imago was homogenized in Pgm buffer (Harris and Hopkinson 1978) with ultrasound and was centrifuged $3 \mathrm{~min}$ at 10,000 g. For allozyme electrophoreses, we used cellulose acetate plates applying standard protocols (Richardson et al. 1986; Hebert and Beaton 1993). A total of 17 allozyme loci were analysed (for details see Junker et al. 2015); in general, allozyme patterns accorded with mitochondrial sequences, but the resolution of allozymes was more fine-grained than mitochondrial information (Junker et al. 2015).

\section{Statistics}

Alleles were labelled according to their relative mobility during electrophoresis, starting with "1" for the slowest. We used G-STAT (Siegismund 1993) to compute allele frequencies and parameters of genetic diversity (i.e. mean number of alleles per locus $A$, expected heterozygosity $H_{\mathrm{e}}$, observed heterozygosity $H_{\mathrm{o}}$, total percentage of polymorphic loci $P_{\text {tot }}$ and percentage of polymorphic loci with the most common allele not exceeding $95 \% P_{95}$ ). Colonies with less than 23 individuals analysed were excluded for the calculation of means for $P_{\text {tot }}$ and $A$ for not being sufficiently representative for these two parameters for an entire colony. Additionally, we calculated the allelic richness $\left(A_{\mathrm{R}}\right)$ with FSTAT (Goudet 1995) to consider the different sample sizes of the locations. This analysis was redone excluding all samples with less than 23 individuals resulting in $A_{\mathrm{R} 23}$.

Locus-by-locus analyses of molecular variance (AMOVA), hierarchical genetic variance analyses, test of Hardy-Weinberg equilibrium and linkage disequilibrium were performed with ARLEQUIN 3.01 (Excoffier et al. 2005), Nei's standard genetic distances (Nei 1972), neighbour-joining phenograms (Saitou and Nei 1987) and bootstraps based on 1,000 replications were calculated with PHYLIP 3.5.c (Felsenstein 1993).

\section{Linking genetic diversity to colony status}

We used Pearson's correlations to investigate the relationships between the parameters of genetic diversity (Table 2) and demography characteristics of the 14 sampled colonies. These characteristics were obtained from MR surveys (details: Zimmermann et al. 2011a, b) or from annual larval nests censuses (NC); see Appendix 1 (Supplementary).

(1) Adult numbers in 2007 (MR), estimated using the Jolly-Seber method, POPAN parametrisation in the MARK package (White and Burnham 1999), based on individuals marked in that year, and split into the number of (1a) males, (1b) females and (1c) total.

(2) Individual adult residency in 2007 (MR). Residency is one of the primary parameters computed by the POPAN method in MARK, which the program uses to estimate colony sizes. It combines mortality and emigration and is inversely related to the time an individual spends within a colony. We used separate estimates of (2a) male, (2b) female and (2c) combined residency.

(3) Larval nest count in 2007 (NC).

(4) Mean nest count over the monitoring period (NC).

(5) Coefficient of variation (CV) from larval nest counts, as an expression of colony stability at each site (NC).

(6) Colony area (hectares) (NC+MR).

(7) Colony connectivity, expressed using three measures: Con1-The average aerial distance to the three closest colonies; Con2-the number of colonies within a $3 \mathrm{~km}$ diameter circle around the focal colony; Con3-aggregated connectivity to all sites within the system, obtained following Moilanen and Nieminen (2002) as,

$S i=\sum_{j \neq i} \exp \left(-\alpha d_{i, j}\right) A_{j}^{\zeta i m}$

The formula weights the distances $d_{i}$ to all known colonies by their areas $A_{i}$, using two of six parameters from the "virtual migration model" of Hanski et al. (2000). The model itself numerically parametrises mark-recapture data, returning the migration scaling coefficient, $\alpha(1 / \alpha \approx$ average movement distance); and immigration scaling coefficient, $\zeta_{\mathrm{im}}$. For a segment of our system, these parameters were estimated from data collected in 2004 in the north-western corner of the central system I (see Fig. 1), and published by Fric et al. (2010). Here, we use $\alpha=0.9$ and $\zeta_{\text {im }}=0.1$, which are rounded averages from numbers originally obtained separately for males and females.

\section{Results}

\section{Colony occupancy turnover}

During 497 annual colony visits from 2001 to 2008, we observed numerous colony extinctions (Table 1). The number of observed recolonisations was expectably lower because an extinction must be observed before a recolonisation is detected. Despite this, the proportion of observed extinctions out of the colony-years monitored, and the proportions of observed recolonisations of the colonies with previously detected extinctions, were roughly equal (extinctions: $4.08 \%$ of colonies x years, recolonisations: $4.01 \%$ ). 


\section{Allozyme analysis}

Thirteen of the 17 loci analysed were polymorphic and showed banding pattern consistent with known quaternary structures (Richardson et al. 1986); the four loci Mdh1, Mdh2, Gpdh and Fum were monomorphic. The number of distinguished alleles was highest in Pep Phe-Pro $_{\text {pith }}$ six (mean $3.62 \pm 1.33 \mathrm{SD}$ ). Allele frequencies for all polymorphic loci are provided on request. The great majority of loci did not deviate from Hardy-Weinberg equilibrium, and only Pep $_{\text {Phe-Pro }}$ deviated significantly in colony 4.1 after Bonferroni correction. No significant linkage disequilibrium was observed. Therefore, we performed further analyses using standard population genetic approaches.

Based on the allele and genotype frequencies, we computed the parameters of population genetic diversity mentioned in the materials and methods section. None of these values was significantly correlated with the number of individuals analysed per sample (Person correlation, all $p \geq 0.1$ ). The values for all colonies with the overall means and standard deviations are given in Table 2.

The total genetic variance of the 14 analysed colonies was 1.255 with 0.070 genetic variance among colonies $\left(F_{\mathrm{ST}}\right.$ : $0.056 ; p<0.001)$ and 0.009 genetic variance among individuals within colonies ( $F_{\mathrm{IS}}: 0.0076$; n.s.) (Table 3$)$. Hierarchical variance analyses revealed a significant genetic differentiation among the three major geographic clusters $\left(F_{\mathrm{CT}}\right.$ : $0.0161 ; p<0.001)$, but represented just $24.4 \%$ of the total variance among colonies; similar results were obtained when colony II is pooled with cluster I or cluster III (Table 4). Genetic distances (Nei 1972) among colonies ranged from 0.0022 to 0.0309 (mean: $0.0130 \pm 0.0068 \mathrm{SD}$ ). Based on

Table 3 Results of non-hierarchical variance analyses among different groups of E. aurinia in western Czech Republic

\begin{tabular}{llcl}
\hline Groups & $F_{S T}$ & $F_{I S}$ & $\begin{array}{l}\text { Variance } \\
\text { within indi- } \\
\text { viduals }\end{array}$ \\
\hline Total & $0.0560^{* *}$ & 0.0076 & $(1.176)$ \\
Group I & $(0.070)$ & $(0.009)$ & \\
Group III & $0.0381^{* *}$ & $0.0862^{*}$ & $(1.281)$ \\
& $(0.056)$ & $(0.121)$ & \\
Subgroup a +c & $0.0523 * *$ & -0.0016 & $(1.151)$ \\
& $(0.063)$ & $(-0.002)$ & \\
Subgroup b & $0.0705^{* *}$ & 0.0011 & $(1.228)$ \\
Subgroup c & $(0.093)$ & $(0.001)$ & \\
& $0.0238 * *$ & -0.0030 & $(1.112)$ \\
& $(0.027)$ & $(-0.003)$ & \\
& 0.0228 & 0.0094 & $(1.213)$ \\
\hline
\end{tabular}

Upper value $=F$ value; lower value $($ in parentheses $)=$ variance component

${ }^{*} p \leq 0.05 ; * * \leq 0.001$; remaining values not significant
Table 4 Results of hierarchical variance analyses among different groups of E. aurinia in western Czech Republic

\begin{tabular}{lllll}
\hline Groups & $F_{C T}$ & $F_{S C}$ & $F_{I S}$ & $\begin{array}{l}\text { Variance } \\
\text { within } \\
\text { individuals }\end{array}$ \\
\hline Group I vs & $0.0220^{* *}$ & $0.0503^{* *}$ & 0.0076 & $(1.176)$ \\
Group II + III & $(0.028)$ & $(0.062)$ & $(0.009)$ & \\
Group I+ II vs & $0.0155^{*}$ & $0.0505^{* *}$ & 0.0076 & $(1.176)$ \\
Group III & $(0.020)$ & $(0.051)$ & $(0.009)$ & \\
Group I vs & $0.0161^{* *}$ & $0.0499 * *$ & 0.0076 & $(1.176)$ \\
Group II vs. group III & $(0.020)$ & $(0.062)$ & $(0.009)$ & \\
\hline
\end{tabular}

Upper value $=F$ value; lower value $($ in parentheses $)=$ variance component

${ }^{*} p \leq 0.05 ; * * \leq 0.001$; remaining values not significant

these, a neighbour joining phenogram was constructed, in which the geographically marginal colonies had more marginal positions than the more central ones (Fig. 2).

Non-hierarchical variance analyses within cluster III within which dispersal among colonies might be less restricted than among clusters (cf. Zimmermann et al. $2011 b)$ revealed an $F_{\mathrm{ST}}$ value of $0.052(p<0.001$; Table 3$)$. A more fine-grained analysis uncovered the highest genetic differentiation in the geographically marginal colonies of this cluster (i.e. IIIa and IIIc) $\left(F_{\mathrm{ST}}: 0.0705 ; p<0.001\right.$; Table 3 ), while the differentiation was considerably lower in the central cluster IIIb $\left(F_{\mathrm{ST}}: 0.0238 ; p<0.001\right)$.

Isolation-by-distance analyses revealed a significant correlation between geographic and genetic distances for all colonies analysed (Mantel test: $r^{2}=0.118 ; p=0.002$ ) and

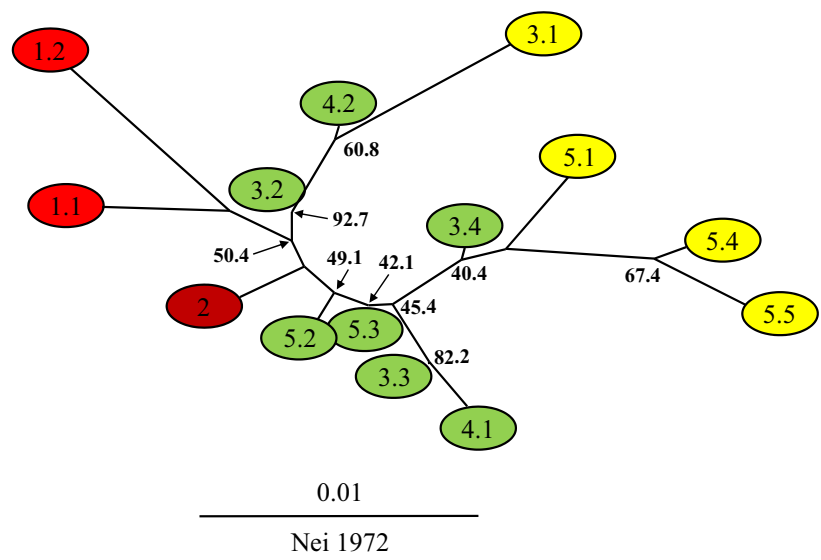

Fig. 2 Neighbour-joining dendrogram with bootstrap values $>40$ (1000 repetitions) for 14 colonies of E. aurinia in western Czech Republic based on genetic distances (Nei, 1972). Colour codes: green-colonies of the central IIIb cluster; yellow-marginal colonies in cluster III (i.e. IIIa and c); red-colonies of cluster I; dark red-colony of cluster II 
for the colonies within cluster III (Mantel test: $r^{2}=0.129$; $p=0.006$ ). However, no such correlation was observed for subgroup IIIb (Mantel test: $r^{2}=0.0027 ; p=0.832$ ).

\section{Genetic versus demography data}

There were very few statistically significant correlations between genetic characteristics of the 14 sampled colonies and their demography characteristics. Still, directions of the correlation coefficients (Table 5) mostly agreed with population genetics predictions. Thus, adult numbers were positively related to all parameters of genetic diversity of the colonies (significantly in case of number of males and $P_{95}$, marginally significantly in case of total number and $P_{95}$ ). Colony area was also positively related to measures of genetic diversity (significantly in case of $P_{95}$ ). Out of the three connectivity measures, only Con2, i.e. the number of colonies within a $3 \mathrm{~km}$ diameter circle, showed consistently positive relationships to genetic measures (significantly in case of $A_{\mathrm{R}}$ ). The correlations were usually negative with adult residency (marginally significant in case of $P_{\text {tot }}$ ), and with larval nest numbers in 2007 (marginally significant for $H_{\mathrm{e}}$ and $P_{\text {tot }}$ ), as well as non-existent (i.e. with very low correlation coefficients) in case of mean nest numbers and its coefficient of variation.

\section{Discussion}

\section{Colony occupancy turnover}

During the decade of following the fates of known E. aurinia colonies in western Czech Republic, we found multiple colony extinctions, as well as subsequent recolonisations, suggesting a rapid colony occupancy turnover, although less rapid than in the textbook metapopulation case of Finnish Melitaea cinxia (Hanski et al. 2017). The similar proportions of observed extinctions and recolonisations of extinct colonies indicated that over the 10 -years monitoring period, the metapopulation system was rather stabilised, not undergoing major decline. Our monitoring data are admittedly much poorer than the meticulously monitored Finnish case, and even the Finnish authors admit such imprecisions as failures to detect larval nests in occupied colonies (Ojanen et al. 2013). There are other differences between ours and the Finnish situation. The majority of the Finnish colonies is very small (average size 0.18 ha, with just a handful of nests), whereas in our situation, the bulk of $E$. aurinia butterflies exist in relatively large colonies (Zimmermann et al. 2011a). It is possible that we consistently failed detecting the very small colonies with presumably most rapid extinction-colonisation dynamics. The obtained difference may be partly due to the differences in the habitats used by these two butterfly species, with $E$. aurinia marshland being less accessible to larval monitoring than $M$. cinxia dry meadow patches. On the other hand, the Finnish landscape seems to be more heterogeneous, with many small farms and homesteads, while the Czech one consists of much larger land use units (cf. Konvicka et al. 2016). Still, the data at hand allow the conjecture that the western Czech Republic colonies of E. aurinia displays rapid extinction-recolonisation dynamics. How this metapopulation system is mirrored in its population genetic structures was the main goal of this study and will be discussed in detail below.

\section{Genetic diversity and differentiation}

The genetic diversity of E. aurinia at the studied regional scale is relatively high (Table 2 ) and even exceeds the average of colonies scattered all over Europe including the assumed glacial refuge areas (Junker et al. 2015). Furthermore, the average genetic diversity of western Bohemian $E$. aurinia colonies was nearly as high as normally observed in widely distributed and common butterfly species (cf. Vandewoestijne et al. 1999; Wood and Pullin 2002; Schmitt et al. 2003, 2005a, b; Habel et al. 2010, 2011; Wendt et al. 2021). It follows that despite strong decline of the species in Central Europe (van Swaay et al. 2010, Brunbjerg et al. 2017) and

Table 5 Pearson's correlation coefficients $(r)$ between within-colony genetic diversity measures, and such colony properties as colony size (adult, larval), adult residence, colony area, and three measures of site connectivity

\begin{tabular}{|c|c|c|c|c|c|c|c|c|c|c|c|c|c|}
\hline & \multicolumn{3}{|c|}{$\begin{array}{l}\text { Adult colony } \\
\text { size (2007) }\end{array}$} & \multicolumn{3}{|c|}{ Adult residence (2007) } & \multicolumn{3}{|c|}{ Larval nest counts } & \multirow[t]{2}{*}{ Area } & \multicolumn{3}{|c|}{ Connectivity measures } \\
\hline & के & 우우 & jot & के & 우아 & o우 & 2007 & Mean (2002-10) & CV (2002-10) & & Con1 & Con2 & Con3 \\
\hline $\mathrm{H}_{\mathrm{e}}$ & 0.256 & 0.041 & 0.210 & -0.045 & -0.301 & -0.210 & $-0.472)$ & 0.040 & -0.109 & 0.334 & 0.108 & 0.326 & -0.005 \\
\hline $\mathrm{H}_{0}$ & 0.302 & 0.170 & 0.280 & 0.013 & -0.310 & -0.180 & -0.389 & 0.251 & -0.102 & 0.325 & 0.222 & 0.159 & -0.115 \\
\hline$P_{\text {tot }}$ & 0.333 & 0.271 & 0.330 & $-0.477)$ & -0.295 & $-0.501^{\prime}$ & $-0.464)$ & -0.040 & -0.300 & 0.280 & 0.353 & 0.125 & $-0.570^{\prime}$ \\
\hline $\mathrm{P}_{95}$ & $0.535^{*}$ & 0.349 & $0.507)$ & -0.021 & -0.119 & -0.086 & -0.452 & -0.090 & -0.390 & $0.518^{*}$ & 0.189 & 0.119 & -0.096 \\
\hline A & 0.372 & 0.252 & 0.354 & -0.238 & -0.099 & -0.221 & -0.286 & -0.002 & -0.051 & 0.294 & -0.018 & 0.362 & -0.117 \\
\hline$A_{R}$ & 0.318 & 0.143 & 0.284 & -0.156 & -0.263 & -0.264 & -0.364 & 0.059 & -0.185 & 0.291 & -0.039 & $0.548^{*}$ & -0.085 \\
\hline
\end{tabular}

*and ' :correlations significant at $p \leq 0.05$ and $p \leq 0.1$ levels, respectively 
in contrast to earlier pessimistic views for the study region (Hula et al. 2004), no remarkable genetic erosion has taken place in western Bohemian colonies. This agrees with both the high number of known colonies and the high overall census numbers (Zimmermann et al. 2011a).

The genetic differentiation among all E. aurinia colonies analysed $\left(F_{S T}: 0.056 ; p<0.001\right)$ was intermediate between the values obtained for strongly dispersing species (e.g. Melanargia galathea; $F_{S T}: 0.033$; Habel et al. 2009) and sedentary species with highly isolated colonies (e.g. Zygaena loti; $F_{S T}$ : 0.136; Habel et al. 2012) in studies covering areas of similar size as ours. Furthermore, we obtained a correlation between genetic and geographic distances (i.e. isolation-by-distance), indicating frequent gene flow among closely situated colonies diminishing towards more distant colonies. However, the isolation by distance was rather weak if compared with other butterfly species (Schmitt et al. 2000; Louy et al., 2007; Habel et al., 2009), explaining only $11.8 \%$ of genetic differentiation. The sum of genetic patterns indicates that the dispersal capacity of E. aurinia in the given landscape with its permeability and regionally high number of suitable sites was sufficient for a regular inter-colony exchange between nearby colonies, but not sufficient for large-scale gene-flow all over the study area.

The rapid recolonisation of vacant colony sites and the large-scale MR (Zimmermann et al. 2011b) also revealed that dispersal of the butterflies between these three larger clusters of colonies was considerably less likely than dispersal within them. Therefore, the observed genetic patterns might not be explained by a metapopulation structure all over the study region with more intense exchange of individuals among neighbouring sites. Rather, the isolation-bydistance equilibrium including all 14 studied colonies may represent an artefact, as numerous geographically close colonies with low genetic differentiation in cluster III contrast with the more distant and more differentiated colonies in clusters I and II. This setting then results in a correlation between genetic and geographic distances without the existence of a classical isolation-by-distance equilibrium.

The isolated cluster II near the city of Cheb (Soos nature reserve) is geographically located halfway between the western cluster I and the eastern cluster III. However, the mean genetic distances (Nei 1972) indicate that this colony is more closely related with the eastern cluster than with the western one (mean genetic distance against eastern cluster: $0.007 \pm 0.002 \mathrm{SD}$; against western cluster: $0.013 \pm 0.007$ SD). This allows arguing that cluster II has formerly derived from the eastern cluster, in a time when suitable habitats still existed in the intermittent area, which is mostly intensively farmed at present.

Focusing the analysis on the eleven colonies of cluster III, they also show a moderate differentiation $\left(F_{S T}\right.$ : 0.052; $p<0.001)$ in the same order of magnitude as all 14 colonies.
However, the strongest differentiation within this cluster is among the marginal colonies (sub-cluster IIIa and IIIc: $F_{S T}$ : $0.071 ; p<0.001)$, while the $F_{S T}$ value among the seven core colonies of IIIb is much lower $\left(F_{S T}: 0.024 ; p<0.001\right)$. This supports the idea of strong gene-flow among the colonies of the core group IIIb. The amount of gene-flow over this wellconnected area is so intense that no isolation-by-distance equilibrium is detected here. However, the more peripheral colonies of the sub-cluster IIIa and IIIc are not fully included in this panmictic area so that somewhat stronger differentiation could become manifested, but due to the relatively small geographic distances, we can assume geneflow among the peripheral and the central colonies within group III. This might be the reason for the establishment of a classical isolation-by-distance equilibrium all over this group of colonies, most likely well connected as one large metapopulation. However, the low but non-significant $F_{\mathrm{ST}}$ value (based on only three colonies analysed) of the northeastern sub-group IIIc, which is consisting of an at least as dense network of colonies as IIIb (Fig. 1), might also stand for an intensive exchange there, but more data is needed for a firm conclusion.

\section{Genetics versus colony demography}

We found only few significant correlations between measures of genetic variability and characteristics of the sampled colonies. This essentially negative result agrees with both the rapid turnover of individual colonies reported here and the frequent dispersal among them detected by Zimmermann et al. (2011b). Both factors probably prevent establishing equilibria between the genetic make-up of individual colonies and their environment. The site parameters used in correlations with the genetic diversity measures varied in degrees of precision (e.g., the colony size estimates are within certain confidence intervals (Zimmermann et al 2011a), larval nest counts diminish in precision with increasing site area (cf. Ojanen et al. 2013)). Still, the obtained results can be discussed in terms of the directions and magnitude of the correlation coefficients.

All the genetic diversity measures responded positively to adult colony size and area occupied. The lack of statistical significance may be due to year-to-year fluctuations in abundance, these patterns are well-known in Melitaeini butterflies (e.g. McLaughlin et al. 2002) and augmented by larval sociality (Peczenye et al. 2017; Kuussaari and Singer 2017); this also applied for our colonies studied for multiple years (Zimmermann et al. 2011a). Moreover, the density dependence detected by Zimmermann et al. (2011a) and the rapid colony turnover suggest that these fluctuations are not synchronised across the system.

Of the three connectivity measures, the number of colonies within a $3 \mathrm{~km}$ circle returned the strongest positive 
correlations. The $3 \mathrm{~km}$ diameter is close to a background dispersal capacity of E. aurinia (Zimmermann et al. 2011b) and other Melitaeinae butterflies (e.g., Wahlberg et al. 2002; Fric et al. 2010; Vodičková et al. 2019). The genetic data also showed minimum differentiation on this scale, and isolationby-distance over larger distances. Average distance to the three nearest colonies probably conveys more limited information on the whole system connectivity, as this measure is much influenced by the position of the focal colony within the entirety of colonies. Finally, the aggregated connectivity measure by Moilanen and Nieminen (2002) appears as useful for systems functioning as well interconnected metapopulations, but failed in our case, which consisted of both a well-connected central cluster and relatively isolated peripheral colonies.

Unexpectedly, the relationships to larval nests counts were mostly negative and adult numbers did not correlate with nests counts $(r=0.308, t=1.12, \mathrm{df}=12, p=0.28)$. Arguably, adult numbers and nests counts may be influenced by different environmental factors (e.g., summer weather affecting adult abundance, autumn mowing affecting larval nests), and although causally interconnected, as there would be no nests without ovipositing females, these two dynamics may be decoupled.

The negative response of genetic diversity to residence is easily explained. This parameter of demographic models (e.g., Schtickzelle et al. 2002) expresses the probability that an individual stays within a colony. It increases with longevity, but decreases with emigration, and it is notoriously difficult to separate the two factors (but see Vlasanek et al. 2009). Due to higher transfer of individuals among more interconnected colonies (i.e., emigration), such colonies (as those within the central cluster) would display lower residence values and would be more diverse genetically (Hanski 2011).

\section{Implications for conservation}

The entirety of E. aurinia colonies in western Bohemia has maintained most of its original genetic diversity and is surviving in a mostly well-connected system, supporting earlier conjectures based on mark-recapture surveys (Zimmermann et al. 2011a, b). It seems less threatened than in many other regions of Western and Central Europe (Schtickzelle et al. 2005; Bos et al. 2006; Bulman et al. 2007; Brunbjerg et al. 2017).

This generally positive situation, however, varies within the study region, depending on the density of adjoining colonies, and probably also on landscape context (cf. Slade et al. 2013; Coristine et al. 2016). Whereas the eastern cluster III and western cluster I contain a relatively high density of colonies within landscapes formed by mosaics of both semi-natural and intensively used grasslands and woodlands, and seem to be well permeable by dispersing individuals, the separate colony forming cluster II, and few other similarly isolated ones (cf. Figure 1), are surrounded by intensive farmland, representing a probably poorly permeable matrix.

Even within the well-connected clusters I and III, many of the colonies are far from safe. While some are located at abandoned lands and are affected by overgrowth with bushes and trees, others are grazed too heavily, or mown too frequently, resulting in periodic destruction of the larval nests (Hula et al. 2004, and unpublished observations). Additionally, many of the colonies contain only relatively low numbers of individuals hereby enhancing their risk of extinction in years with less favourable weather conditions or high pressure of parasitoids. This is particularly affecting the peripheral colonies of cluster III only linked by occasional exchange events with the respective core, but representing an important contribution to the regional genetic diversity due to their genetic differentiation. Future conservation measures therefore should focus on two main aspects: (i) Considering more in depth the habitat requirements of $E$. aurinia for future management plans and (ii) stabilisation strategies for the peripheral colonies e.g. by enlarging their area via habitat restoration. By these means, the general survival capacity of the existing colonies with their important genetic resources could be enhanced in western Bohemia.

Furthermore, the integration of the isolated cluster II colony into the eastern metapopulation system should be envisaged as the risk of extinction is particularly high in such isolated colonies (cf. Hanski 1999). The establishment of stepping-stone habitats should be an appropriate measure to re-establish and enhance the regular exchange of individuals and thus reduce the risk of a colony crash in unsuitable years.

Another approach appears recommendable for cluster I in the Czech-German border region. As two major genetic lineages are meeting in this region (Junker et al. 2015), it is still unresolved whether (i) this cluster belong to a western Central European genetic lineage, (ii) is of hybrid origin between these two genetic lineages as observed for other butterfly species in some parts of Bohemia (Schmitt and Müller 2007; Schmitt and Zimmermann 2012) or (iii) belongs to the same genetic lineage as the other western Bohemian E. aurinia colonies analysed. Therefore, it should be recommended to conserve these westernmost colonies as own management unit till this question could be finally resolved. Important information could be obtained by additional genetic analyses, ideally using more informative DNA markers and including also E. aurinia colonies from Saxony (eastern Germany).

Supplementary Information The online version contains supplementary material available at https://doi.org/10.1007/s10841-021-00325-8. 
Acknowledgements We acknowledge the DFG for financing the scholarship of Marius Junker and the laboratory consumables in the graduate school "Verbesserung von Normsetzung und Normanwendung im integrierten Umweltschutz durch rechts- und naturwissenschaftliche Kooperation; no. 1319" at Trier University. Czech Technological Agency (SS01010526) funded finishing the paper. Zdeněk Fric and Přemysl Tájek contributed valuable consultations. Furthermore, we thank Czech Conservation Authority for the permits to sample the butterflies.

Funding Open Access funding enabled and organized by Projekt DEAL.

\section{Declarations}

Conflicts of interest The authors declare that they have no conflict of interest.

Ethical approval The authors confirm that they follow the rules of good scientific practice and all ethical standards requested by the journal.

Open Access This article is licensed under a Creative Commons Attribution 4.0 International License, which permits use, sharing, adaptation, distribution and reproduction in any medium or format, as long as you give appropriate credit to the original author(s) and the source, provide a link to the Creative Commons licence, and indicate if changes were made. The images or other third party material in this article are included in the article's Creative Commons licence, unless indicated otherwise in a credit line to the material. If material is not included in the article's Creative Commons licence and your intended use is not permitted by statutory regulation or exceeds the permitted use, you will need to obtain permission directly from the copyright holder. To view a copy of this licence, visit http://creativecommons.org/licenses/by/4.0/.

\section{References}

Baguette M (2003) Long distance dispersal and landscape occupancy in a metapopulation of the cranberry fritillary butterfly. Ecography 26:153-160

Baguette M, Petit S, Quéva F (2000) Population spatial structure and migration of three butterfly species within the same habitat network: consequences for conservation. J Appl Ecol 37:100-108

Bos F, Bosveld M, Groenendijk D, van Swaay C, Wynhoff I (2006) De Dagvlinders van Nederlands. KNNV Publishing, Nederlands, p 380

Brunbjerg AK, Hoye TT, Eskildsen A, Nygaard B, Damgaard CF, Ejrnaes R (2017) The collapse of marsh fritillary (Euphydryas aurinia) populations associated with declining host plant abundance. Biol Conserv 211:117-124

Bulman CR, Wilson RJ, Holt AR, Bravo LG, Early RI, Warren MS, Thomas CD (2007) Minimum viable metapopulation size, extinction debt, and the conservation of a declining species. Ecol Appl 17:1460-1473

Colombo EH, Anteneodo C (2015) Metapopulation dynamics in a complex ecological landscape. Phys Rev E 92:022714

Coristine LE, Soroye P, Soares RN, Robillard C, Kerr JT (2016) Dispersal limitation, climate change, and practical tools for butterfly conservation in intensively used landscapes. Nat Areas J $36: 440-452$

Excoffier L, Laval G, Schneider S (2005) Arlequin ver. 3.0: an integrated software package for population genetics data analysis. Evol Bioinform 1:47-50
Felsenstein J (1993) PHYLIP (phylogeny inference package) ver. 3.5.c. University of Washington, Washington

Fric Z, Hula V, Klimova M, Zimmermann K, Konvicka M (2010) Dispersal of four fritillary butterflies within identical landscape. Ecol Res 25:543-552

Goudet J (1995) FSTAT (version 1.2): a computer program to calculate F-statistics. Heredity 86:485-486

Habel JC, Schmitt T (2012) The burden of genetic diversity. Biol Conserv 147:270-274

Habel JC, Schmitt T (2018) Vanishing of the common species: empty habitats and the role of genetic diversity. Biol Conserv 218:211-216

Habel JC, Meyer M, Schmitt T (2009) The genetic consequence of differing ecological demands of a generalist and a specialist butterfly species. Biodivers Conserv 18:1895-1908

Habel JC, Rödder D, Stefano S, Meyer M, Schmitt T (2010) Strong genetic cohesiveness between Italy and North Africa in four butterfly species. Biol J Linn Soc 99:818-830

Habel JC, Lens L, Rödder D, Schmitt T (2011) From Africa to Europe and back: refugia and range shifts cause high genetic differentiation in the European marbled white butterfly Melanargia galathea. BMC Evol Biol 11:215

Habel JC, Engler J, Rödder D, Schmitt T (2012) Landscape genetics of a recent population extirpation in a burnet moth species. Conserv Genet 13:247-255

Habel JC, Samways M, Schmitt T (2019) Mitigating the precipitous decline of terrestrial European insects: requirements for a new strategy. Biodiv Conserv 28:1343-1360

Hanski I (1999) Metapopulation ecology. Oxford University Press, UK, p 328

Hanski I (2011) Eco-evolutionary spatial dynamics in the Glanville fritillary butterfly. P Natl Acad Sci USA 108:14397-14404

Hanski I, Alho J, Moilanen A (2000) Estimating the parameters of survival and migration of individuals in metapopulations. Ecology 81:239-251

Hanski I, Schulz T, Wong SC, Ahola V, Ruokolainen A, Ojanen SP (2017) Ecological and genetic basis of metapopulation persistence of the Glanville fritillary butterfly in fragmented landscapes. Nat Commun 8:14504

Harris H, Hopkinson DA (1978) Handbook of enzyme electrophoresis in human genetics. North-Holland, Amsterdam

Hebert PDN, Beaton MJ (1993) Methodologies for allozyme analysis using cellulose acetate electrophoresis. Helena Laboratories, Texas, p 32

Hill JK, Thomas CD, Lewis OT (1996) Effects of habitat patch size and isolation on dispersal by Hesperia comma butterflies: implications for metapopulation structure. J Anim Ecol 65:725-735

Hula V, Konvicka M, Pavlicko A, Fric Z (2004) Marsh fritillary (Euphydryas aurinia) in the Czech Republic: monitoring, metapopulation structure, and conservation of an endangered butterfly. Entomol Fennica 15:231-241

Junker M, Schmitt T (2010) Demography, dispersal and movement pattern of Euphydryas aurinia (Lepidoptera: Nymphalidae) at the Iberian Peninsula: an alarming example in an increasingly fragmented landscape? J Insect Conserv 14:237-246

Junker M, Wagner S, Gros P, Schmitt T (2010) Changing demography and dispersal behaviour: ecological adaptation in an alpine butterfly. Oecologia 164:971-980

Junker M, Zimmermann M, Ramos AA, Gros P, Konvicka M, Neve G, Rakosy L, Tammaru T, Castilho R, Schmitt T (2015) Three in one-multiple faunal elements within an endangered European butterfly species. PLoS One 10:e0142282

Kadlec T, Vrba P, Kepka P, Schmitt T, Konvicka M (2010) Tracking the decline of the once-common butterfly: delayed oviposition, demography and population genetics in the hermit Chazara briseis. Anim Conserv 13:172-183 
Konvicka M, Hula V, Fric Z (2003) Habitat of pre-hibernating larvae of the endangered butterfly Euphydryas aurinia (Lepidoptera : Nymphalidae): what can be learned from vegetation composition and architecture? Eur J Entomol 100:313-322

Konvicka M, Zimmermann K, Klimova M, Hula V, Fric Z (2012) Inverse link between density and dispersal distance in butterflies: field evidence from six co-occurring species. Popul Ecol 54:91-101

Konvicka M, Benes J, Polakova S (2016) Smaller fields support more butterflies: comparing two neighbouring European countries with different socioeconomic heritage. J Insect Conserv 20:1113-1118

Korb SK, Bolshakov LV, Fric ZF, Bartonova A (2016) Cluster biodiversity as a multidimensional structure evolution strategy: checkerspot butterflies of the group Euphydryas aurinia (Rottemburg, 1775) (Lepidoptera: Nymphalidae). Syst Entomol 41:441-457

Kramp K, Cizek O, Madeira PM, Ramos AA, Konvicka M, Castilho R, Schmitt T (2016) Genetic implications of the phylogeographical patterns in the conservation of the boreal wetland butterfly Colias palaeno (Pieridae). Biol J Linn Soc 119:1068-1081

Kuussaari M, Singer MC (2017) Group size, and egg and larval survival in the social butterfly Melitaea cinxia. Ann Zool Fenn $54: 213-223$

Louy D, Habel JC, Schmitt T, Meyer M, Assmann T, Müller P (2007) Strongly diverging population genetic patterns of three skipper species: isolation, restricted gene flow and panmixis. Conserv Genet 8:671-681

Louy D, Habel JC, Abadjev S, Rakosy L, Varga Z, Rödder D, Schmitt $\mathrm{T}$ (2014) Molecules and models indicate diverging evolutionary effects from parallel altitudinal range shifts in two mountain Ringlet butterflies. Biol J Linn Soc 112:569-583

Madsen T, Shine R, Olsson M, Wittzell H (1999) Restoration of an inbred adder population. Nature 402:34-35

Madsen T, Olsson M, Wittzell H, Stille B, Gullberg A, Shine R, Andersson S, Tegelström H (2000) Population size and genetic diversity in sand lizards (Lacerta agilis) and adders (Vipera berus). Biol Conserv 94:257-262

McLaughlin JF, Hellmann JJ, Boggs CL, Ehrlich PR (2002) The route to extinction: population dynamics of a threatened butterfly. Oecologia 132:538-548

Meister H, Lindman L, Tammaru T (2015) Testing for local monophagy in the regionally oligophagous Euphydryas aurinia (Lepidoptera: Nymphalidae). J Insect Conserv 19:691-702

Moilanen A, Nieminen M (2002) Simple connectivity measures in spatial ecology. Ecology 83:1131-1145

Nabielec J, Nowicki P (2015) Drivers of local densities of endangered Lycaena helle butterflies in a fragmented landscape. Popul Ecol 57:649-656

Nei M (1972) Genetic distances between populations. Amer Nat 106:283-291

Ojanen SP, Nieminen M, Meyke E, Pöyry J, Hanski I (2013) Long-term metapopulation study of the Glanville fritillary butterfly (Melitaea cinxia): survey methods, data management, and long-term population trends. Ecol Evol 3:3713-3737

Orsini L, Corander J, Alasentie A, Hanski I (2008) Genetic spatial structure in a butterfly metapopulation correlates better with past than present demographic structure. Mol Ecol 17:2629-2642

Pecsenye K, Toth A, Bereczki J, Varga Z (2017) A possible genetic basis for vulnerability in Euphydryas maturna (Lepidoptera: Nymphalidae). Genetica 145:151-161

Richardson BJ, Baverstock PR, Adams M (1986) Allozyme electrophoresis. A handbook for animal systematics and population studies. Academic Press, San Diego, p 420

Saccheri I, Kuussaari M, Kankare M, Vikman P, Fortelius W, Hanski I (1998) Inbreeding and extinction in a butterfly metapopulation. Nature 392:491-494
Saitou N, Nei M (1987) The neighbor-joining method: a new method for reconstructing phylogenetic trees. Mol Biol Evol 4:406-425

Schmitt T, Müller P (2007) Limited hybridization along a large contact zone between two genetic lineages of the butterfly Erebia medusa (Satyrinae, Lepidoptera) in Central Europe. J Zool Syst Evol Res 45:39-46

Schmitt T, Zimmermann M (2012) To hybridize or not to hybridize: what separates two genetic lineages of the Chalk-hill Blue Polyommatus coridon (Lycaenidae, Lepidoptera) along their secondary contact zone throughout eastern Central Europe? J Zool Syst Evol Res 50:106-115

Schmitt T, Varga Z, Seitz A (2000) Forests as dispersal barriers for Erebia medusa (Nymphalidae, Lepidoptera). Basic Appl Ecol 1:53-59

Schmitt T, Gieß1 A, Seitz A (2003) Did Polyommatus icarus (Lepidoptera: Lycaenidae) have distinct glacial refugia in southern Europe?-Evidence from population genetics. Biol J Linn Soc 80:529-538

Schmitt T, Röber S, Seitz A (2005) Is the last glaciation the only relevant event for the present genetic population structure of the meadow brown butterfly Maniola jurtina (Lepidoptera: Nymphalidae)? Biol J Linn Soc 85:419-431

Schmitt T, Varga Z, Seitz A (2005) Are Polyommatus hispana and Polyommatus slovacus bivoltine Polyommatus coridon (Lepidoptera: Lycaenidae)? The discriminatory value of genetics in the taxonomy. Org Divers Evol 5:297-307

Schtickzelle N, Le Boulenge E, Baguette M (2002) Metapopulation dynamics of the bog fritillary butterfly: demographic processes in a patchy population. Oikos 97:349-360

Schtickzelle N, Choutt J, Goffart P, Fichefet V, Baguette M (2005) Metapopulation dynamics and conservation of the marsh fritillary butterfly: population viability analysis and management options for a critically endangered species in western Europe. Biol Conserv 126:569-581

Shuey J, Jacquart E, Orr S, Becker F, Nyberg A, Littiken R, Anchor T, Luchik D (2016) Landscape-scale response to local habitat restoration in the regal fritillary butterfly (Speyeria idalia) (Lepidoptera: Nymphalidae). J Insect Conserv 20:773-780

Siegismund HR (1993) G-Stat, ver. 3. Genetical statistical programs for the analysis of population data. The Arboretum, Royal Veterinary and Agricultural University, Denmark

Sigaard P, Pertoldi C, Madsen AB, Søgaard B, Loeschcke V (2008) Patterns of genetic variation in isolated Danish populations of the endangered butterfly Euphydryas aurinia. Biol J Linn Soc 95:677-687

Singer MC, Stefanescu C, Pen I (2002) When random sampling does not work: standard design falsely indicates maladaptive host preferences in a butterfly. Ecol Lett 5:1-6

Slade EM, Merckx T, Riutta T, Bebber DP, Redhead D, Riordan P, Macdonald DW (2013) Life-history traits and landscape characteristics predict macro-moth responses to forest fragmentation. Ecology 94:1519-1530

Slancarova J, Benes J, Kristynek M, Kepka P, Konvicka M (2014) Does the surrounding landscape heterogeneity affect the butterflies of insular grassland reserves? A contrast between composition and configuration. J Insect Conserv 18:1-12

Tshikolovets V (2011) Butterflies of Europe and the mediterranean area. Vladim Tshikolovets, Pardubice

Újvári B, Madsen T, Kotenko T, Olsson M, Shine R, Wittzell H (2002) Low genetic diversity threatens imminent extinction for the Hungarian meadow viper (Vipera ursinii rakosiensis). Biol Conserv 105:127-130

Van Swaay C, Cuttelod A, Collins S, Maes D, López Munguira M, Šašić M, Settele J, Verovnik R, Verstrael T, Warren M, Wiemers M, Wynhof I (2010) European red list of butterfies. Publications Office of the European Union, Luxembourg 
Vandewoestijne S, Néve G, Baguette M (1999) Spatial and temporal population genetic structure of the butterfly Aglais urticae L. (Lepidoptera, Nymphalidae). Mol Ecol 8:1539-1543

Vlasanek P, Hauck D, Konvicka M (2009) Adult sex ratio in the Parnassius mnemosyne butterfly: effects of survival, migration, and weather. Isr J Ecol Evol 55:233-252

Vodičková V, Vrba P, Grill S, Bartonova A, Kollross J, Potocký P, Konvička M (2019) Will refaunation by feral horse affect five checkerspot butterfly species (Melitaea Fabricius, 1807) coexisting at xeric grasslands of Podyji National Park, Czech Republic? J Nature Conserv 52:125755

Wahlberg N, Klemetti T, Hanski I (2002) Dynamic populations in a dynamic landscape: the metapopulation structure of the marsh fritillary butterfly. Ecography 25:224-232

Wendt M, Husemann M, Kramp K, Schmitt T (2021) Reconstruction of forest dynamics in the western Palaearctic based on phylogeographic analysis of the ringlet butterfly Erebia aethiops. Sci Rep 11:201

White GC, Burnham KP (1999) Program mark: survival estimation from populations of marked animals. Bird Study 46:120-138

Wood BC, Pullin AS (2002) Persistence of species in a fragmented urban landscape: the importance of dispersal ability and habitat availability for grassland butterflies. Biodivers Conserv 11:11451-11468
Zimmermann K, Hula V, Fric Z, Konvicka M (2010) Příběh evropsky významného druhu hnědáska chrastavcového: Devět let monitoringu a ochrany v západních Čechách. In: Brabec J (ed) A butterfly of community interest, the marsh fritillary: nine years of monitoring and conservation in western Bohemia. Přírodní Fenomény a Zajímavosti Západních Čech, Mezi Lesy, pp 85-99

Zimmermann K, Blazkova P, Cizek O, Fric Z, Hula V, Kepka P, Novotny D, Slamova I, Konvicka M (2011) Adult demography in the marsh fritillary butterfly, Euphydryas aurinia (Rottenburg, 1775) in the Czech Republic: patterns across sites and seasons. Eur J Entomol 108:243-253

Zimmermann K, Fric Z, Jiskra P, Kopeckova M, Vlasanek P, Zapletal M, Konvicka M (2011) Mark-recapture on large spatial scale reveals long distance dispersal in the Marsh Fritillary, Euphydryas aurinia. Ecol Entomol 36:499-510

Publisher's Note Springer Nature remains neutral with regard to jurisdictional claims in published maps and institutional affiliations. 